\title{
MANAJEMEN PENDIDIKAN DI SEKOLAH DASAR DALAM PENGEMBANGAN KEWIRAUSAHAAN
}

\section{EDUCATION MANAGEMENT IN ELEMENTARY SCHOOLS IN THE DEVELOPMENT OF ENTREPRENEURSHIP}

\author{
Nur Zaytun Hasanah*1, Nurafni² \\ ${ }^{1}$ Program Studi Pendidikan Agama Islam, Fakultas Ilmu Agama Islam, \\ Universitas Islam Indonesia, Indonesia \\ ${ }^{2}$ Program Studi Ahwal Syakshiyyah, Fakultas Ilmu Agama Islam, \\ Universitas Islam Indonesia, Indonesia \\ e-mail:*18422098@students.uii.ac.id, 220421026@students.uii.ac.id
}

\begin{abstract}
ABSTRAK
Guru memiliki andil yang sangat besar terhadap keberhasilan siswa di sekolah dalam mengembangkan minat kewirausahaan. Kepala sekolah juga berperan penting dalam membantu para guru mewujudkan minat siswa dalam pengembangan kewirausahaan. Akan tetapi, di era sekarang ini masih ada sekolah-sekolah yang belum maksimal dalam mengembangkan minat kewirausahaan pada jiwa siswa. Sehingga, angka pengangguran di Indonesia semakin lama semakin meningkat. Tujuan dari penelitian ini adalah untuk menginterpretasikan pentingnya manajemen pendidikan dalam pengembangan kewirausahaan. Penelitian ini merupakan jenis penelitian kualitatif dengan pendekatan penelitian deskripsi kualitatif. Teknik pengumpulan data yang digunakan yaitu metode observasi, metode dokumentasi dan metode wawancara. Teknik analisis data yang digunakan ialah Miles, Huberman dan Saldana dengan tahapan koleksi data, kondensasi data, penyajian data dan penarikan kesimpulan. Hasil penelitian menunjukkan pengembangan kewirausahaan yang dilaksanakan di SD Muhammadiah Pakem dilakukan dengan berbagai cara, diantaranya: 1) membekali guru dengan materi kewirausahaan; 2) mengintegrasikan dalam muatan pelajaran; 3) menyediakan sarana dan fasilitas pendukung; 4) membuat kegiatan berbasis kewirausahaan, serta 5) bekerja dengan orang tua.
\end{abstract}

Kata kunci: Manajemen, Pendidikan, Kewirausahaan

\begin{abstract}
Teachers have a very big role in the success of students in schools in developing entrepreneurial interests. So is the head of the school. Principals play an important role in helping teachers to realize students' interest in the development of entrepreneurship. However, in the current era there are still schools that are not optimal in developing entrepreneurial interest in the soul of students. Thus, the unemployment rate in Indonesia is increasing over time. The purpose of this study is to interpret the importance of educational management in the development of sharia entrepreneurship. This research is a type of qualitative research with a qualitative descriptive research approach. Data collection techniques used are observation methods, documentation methods and interview methods. The data analysis technique used is Miles, Huberman and Saldana with the stages of data collection, data condensation, data presentation and drawing conclusions. The results of the study show that entrepreneurship development carried out at SD Muhammadiah Pakem is carried out in various ways, including: 1) equipping teachers with entrepreneurship materials; 2) integrate in the content of the lesson; 3) provide supporting facilities and facilities; 4) create entrepreneurship-based activities, and 5) colaboration with parents.
\end{abstract}

Keywords: Education, Entrepreneurship 


\section{PENDAHULUAN}

Manajemen pendidikan sangat berkaitan dengan upaya untuk menciptakan dan mempertahankan fungsi dan kedudukan lembaga, termasuk sekolah. Guru memiliki andil yang sangat besar terhadap keberhasilan siswa di sekolah dalam mengembangkan minat kewirausahaan. Guru melaksanakan dua kegiatan pokok yaitu kegiatan mengajar dan mendidik siswanya, agar mampu mencetak generasi yang pandai dan terampil dalam menciptakan sebuah karya, memiliki jiwa bisnis yang kreatif dan inovatif, demi kemajuan bangsa dan agama. Salah satunya adalah dengan mengembangkan minat kewirausahaan siswa.

Kewirausahaan itu sendiri memiliki arti yaitu kegiatan untuk membuka usaha dalam berbagai kesempatan dan berani mengambil resiko. Seorang wirausaha harus mampu mengembangkan bisnis yang Islami. Bisnis yang dijalani juga diharuskan dijalankan dengan penuh keikhlasan beribadah hanya semata-mata mendapatkan keridhaan-Nya [1]. Berwirausaha yang dicontohkan Rasulullah saw adalah berbisnis atau berdagang. Rasulullah sangat menganjurkan umatnya untuk berdagang dan berbisnis: "berdaganglah kamu, sebab dari sepuluh bagian penghidupan, sembilan diantaranya dihasilkan dari berdagang" (HR. Bukhari) [1]. Seorang wirausaha dituntut harus bersikap jujur, adil, dan tidak menzalimi serta menjauhkan diri dari hal-hal yang diharamkan oleh Allah, termasuk menjauhkan diri dari yang namanya riba dalam dalam menjalankan aktivitas bisnisnya.

Kewirausahaan dalam perspektif Islam tidak hanya sebatas ringkasan konsep sederhana terkait kewirausahaan dan Islam. Akan tetapi, ada tiga pilar yang mendukung kewirausahaan dilihat dari perspektif Islam [2]. Pilar pertama yaitu mengejar terbukanya peluang yang luas. Hal ini mengacu pada konsep kewirausahaan bahwa seorang pelaku usaha adalah orang yang mengeksploitasi kesempatan melalui penggabungan ulang sumber daya. Pilar kedua yaitu sosial ekonomi atau nilai etika.

Kewirausahaan dalam perspektif Islam dipandu oleh sekumpulan norma, nilai dan perilaku terpuji. Pilar ketiga adalah aspek spiritual agama dan hablumminallah atau hubungan manusia dengan Allah, dengan tujuan utama yaitu untuk memuliakan dan mencapai ridha Allah [3]. Selain itu, siswa juga harus diberikan pengetahuan tentang cara bagaimana mereka berkomunikasi dengan orang lain, agar mereka lebih mengerti dan paham dalam menjiwai wirausaha. Kemudian, dengan cara mengajarkan bagaimana berinteraksi terhadap lingkungan dengan cara melatih dalam hal komunikasi dan sosial mereka baik di dalam kelas, di luar kelas, dan lingkungan luar sekolah [4].

Di sekolah dasar sendiri, pengembangan minat kewirausahaan masih banyak yang belum optimal. Hal ini karena ranah psikomotor yang dikembangkan belum mengarah pada pengembangan minat kewirausahaan, kecuali sekolah memang memiliki program sendiri terkait kewirausahaan. Hal ini berarti, pengembangan kewirausahaan di sekolah dasar tentu dapat dikembangkan tergantung dari program sekolah. Program kewirausahaan di sekolah dasar dapat terintegrasi dalam proses belajar mengajar, menjadi salah satu program ekstrakulikuler, serta muatan pembelajaran kewirausahaan yang berdiri sendiri [5]. Salah satu sekolah yang telah menerapkan pengembangan kewirausahaan adalah SD Muhammadiyah Pakem. Penelitian ini sangat perlu untuk dilakukan agar dapat menjabarkan pengelolaan menejemen pendidikan di sekolah dasar, khususnya dalam mengembangkan minat kewirausahaan pada siswa.

\section{METODE PENELITIAN}

Jenis penelitian ini adalah penelitian lapangan, yaitu penelitian yang mengambil data dari lapangan dan dilakukan di sekolah yang sebenarnya untuk menemukan realitas apa yang tengah terjadi mengenai masalah tersebut. Pendekatan penelitian ini adalah penelitian deskriptif kualitatif. Penelitian ini ditujukan untuk mendeskripsikan dan mengeksplorasi mengenai manajemen pendidikan di Sekolah Dasar Muhammadiyah Pakem dalam pengembangan kewirausahaan bagi siswa. Pendekatan ini dipilih oleh peneliti untuk menekankan pada aspek pemahaman secara menyeluruh, mendalam, dan rinci terhadap manajemen pendidikan dalam pengembangan kewirausahaan di SD Muhammadiyah Pakem yang terletak di Jalan Kaliurang 
No.27, Gambiran, Pakembinangun, Pakem, Sleman, Yogyakarta pada objek penelitian. Data yang digunakan dalam penelitian ini dapat diklasifikasikan menjadi: 1) Data primer, yaitu data yang diperoleh secara langsung dari objek yang diteliti. Termasuk di dalam data primer adalah hasil wawancara dengan kepala SD Muhammadiyah Pakem. 2) Data sekunder, yaitu data yang diperoleh dari selain sumber primer (sumber kedua, ketiga, dst). Termasuk dalam data sekunder adalah data pendukung yang berasal dari jurnal, buku, majalah, surat kabar, artikel, internet, dan media sosial yang berhubungan dengan objek penelitian.

Dalam penelitian ini, prosedur pengumpulan data yang dilakukan oleh peneliti adalah sebagai berikut: 1) Metode wawancara. Dalam penelitian ini, peneliti berusaha mencari informasi melalui wawancara dengan informan terkait. Berkaitan dengan penelitian kualitatif, maka peneliti menentukan informan yang diharapkan dapat memberikan informasi sesuai dengan fokus penelitian. Para informan ini dipilih berdasarkan kriteria tertentu, diantaranya bahwa informan tidak hanya sekedar tahu dan dapat memberikan informasi, tetapi juga telah menghayati secara sungguh-sungguh sebagai akibat dari keterlibatannya yang cukup lama dengan lingkungan atau kegiatan yang bersangkutan. 2) Metode observasi. Observasi dilakukan dengan mengamati secara langsung ke objek penelitian dengan tujuan untuk memperoleh gambaran yang mendetail dalam rangka memperoleh data yang akurat sehingga akan tercapai suatu pembahasan dalam penelitian ini. 3) Metode dokumentasi, yaitu teknik pengumpulan data dengan menghimpun dan menganalisis dokumen-dokumen baik dokumen yang berbentuk tulisan, gambar, atau karyakarya monumental dari seseorang. Dokumentasi dilakukan dengan menelaah dokumen-dokumen yang berkaitan dengan penelitian, termasuk sumber-sumber sekunder.

Adapun teknik analisis data yang digunakan dalam penelitian ini adalah model interaktif yang meliputi koleksi data, kondensasi data, penyajian data, dan penarikan kesimpulan atau verifikasi. Faktor kegagalan pada penelitian yang dihadapi adalah jika peneliti tidak menjadi bagian dari pihak sekolah itu sendiri. Akan tetapi, peneliti memiliki strategi untuk menemukan bagaimana cara mengembangkan kewirausahaan dalam manajemen pendidikan di Sekolah Dasar Muhammadiyah Pakem, yaitu dengan cara peneliti terjun langsung untuk menjadi bagian dari sekolah itu sendiri. Risiko yang memunculkan kegagalan pada penelitian ini, tidak lepas dari pihak-pihak yang terlibat. Untuk mensukseskan penelitian ini, peneliti berupaya berkomunikasi secara intensif dengan pihak sekolah.

\section{Hasil Penelitian}

\section{HASIL DAN PEMBAHASAN}

Berdasarkan dari hasil wawancara dengan kepala sekolah di Sekolah Dasar Muhammadiyah Pakem, didapatkan bahwa manajemen pendidikan sangat berkaitan erat dengan upaya untuk menciptakan dan mempertahankan fungsi dan kedudukan sekolah. Sebelum menciptakan kewirausahaan di lingkungan sekolah, perlunya ada peningkatan kualitas guru. Hal ini dimaksudkan, agar yang hal-hal yang disampaikan kepada para siswa dapat maksimal dan sesuai dengan target dari sekolah. Selanjutnya, peningkatan kualitas guru yang dimaksud yaitu dari kompetensi kepribadian, kompetensi supervisi, kompetensi manajerial, kompetensi sosial, dan kompetensi kewirausahaan.

Hal-hal yang dilakukan di sekolah dasar Muhammadiyah Pakem terkait pengembangan kewirausahaan dapat dikatagorikan menjadi pengembangan eksternal dan internal. Pada pengembangan eksternal dilakukan dengan promosi baik di sosial media ataupun ke sekolahsekolah, atau bisa juga kepada masyarakat. Sedangkan untuk pengembangan kewirausahaan secara internal berupa pembuatan pamflet, memberikan beberapa gambaran kepada para siswa mengenai kewirausahaan. Selain itu juga memperkenalkan kepada siswa tentang orang-orang yang telah berhasil dari kewirausahaan. Pengembangan kewirausaahan yang disampaikan kepada siswa juga menekankan keseimbangan teori dan praktik. Selain itu juga disampaikan dengan cara yang menarik agar siswa tidak bosan.

Guru dalam pengembangan kewirausahaan juga memiliki peran penting bagi siswa. Guru akan mendapatkan pembinaan secara langsung dari kepala sekolah. Selain itu juga ada penilaiaan 
Jurnal Ilmiah KONTEKSTUAL, Volume.3, No.1, Agustus 2021, pp. 78-84

kinerja setiap satu semester dari guru dan karyawan dengan secara penilaian tersendiri. Kemudian di akhir tahun, di sekolah ini juga ada penugasan yang selalu berubah sesuai dengan hasil penilaian kinerja. Selain itu, pembelajaran yang ada di sekolah ini juga sudah berorientasi pada pengembangan kewirausahaan. Sekolah ini juga memiliki semangat dan motivasi untuk dapat memberdayakan semua hal yang ada di dalam sekolah itu sendiri yang tergambar dalam visi misi SD Muhammadiyah Pakem.

Seperti yang diungkapkan oleh Ibu Afi selaku Kepala Sekolah Dasar Muhammadiyah Pakem bahwasanya mata pelajaran yang berkaitan erat dengan kewirausahaan yaitu Matematika, IPS, dan SPdB. Ketiga mata pelajaran ini sangat berkaitan erat dengan kewirausahaan yang dikembangkan di SD Muhammadiyah Pakem. Para siswa juga diajarkan untuk membuat sesuatu yang dapat dijual. Hal-hal yang diajarkan, seperti membuat jus, membuat mainan dari dos bekas ataupun tas dari sampah plastik. Para siswa juga dibekali cara menghitung pemasukan dan juga pengeluaran. Siswa juga diajarkan cara menghitung kerugian dan juga keutungan yang kira-kira akan mempengaruhi pemasukan dan juga pengeluaran. Siswa juga mempelajari cara berinteraksi dengan teman-teman, bapak-bapak dan ibu-ibu untuk menawarkan jualan mereka dengan cara dan sikap yang baik. Tidak hanya itu, pengembangan kewirausahaan juga disampaikan dengan mengimplementasikan nilai-nilai karakter, seperti jujur ketika menimbang barang ataupun jujur ketika berjualan, menghindari adanya utang barang, dan lain-lain.

Selain mata pelajaran yang berkaitan dengan kewirausahaan, ada beberapa hal juga yang dilakukan untuk menumbuhkan jiwa kewirausahaan pada setiap masing-masing siswa. Seperti dengan berkunjung ke usaha milik orang tua siswa. Hal ini dapat memberikan pengalaman baru dan pandangan baru kepada siswa-siswi tentang dunia kewirausahaan. Selain itu, strategi yang dilakukan oleh guru-guru berupa diskusi ringan mengenai usaha-usaha yang dapat dibuat oleh siswa, atau dengan menonton video tentang cara mengelola sampah plastik, dll. Para siswa juga tidak bisa untuk dituntut harus bisa pada satu hal ini, melainkan dengan mengklasifikasikan siswasiswi yang bisa mengelola atau yang membuat, mewarnai, menjahit ataupun yang melukis. Agar siswa-siswi tidak merasa dipaksa dan tentunya hati mereka pun senang ketika melakukan kewirausahaan tersebut.

Guna mendukung pengembangan kewirausahaan, sekolah juga membangun tempat untuk meletakan kerajinan tangan maupun hasil produk yang telah dibuat oleh para siswa. Adapun untuk sistemnya yaitu siapa saja boleh menitipkan produknya di toko tersebut. Selanjutnya, untuk pembagian hasilnya itu tergantung kesepakatan diawal dengan guru-guru. Orang tua siswa pun juga bisa menitipkan barang dagangannya di toko itu. Bentuk interaksi yang dilakukan pada saat itu adalah antara siswa-siswi dan pembeli yang dilakukan secara face to face, sehingga siswasiswi bisa merasakan bagaimana rasanya memiliki usaha, menerima uang, memutarnya kembali untuk usaha berikutnya. Sedangkan sekarang ini, Pandemi Covid-19 yang menyebabkan semuanya serba online sebagai bentuk mematuhi protokol harus tetap dipatuhi. Oleh karena itu, guru-guru berusaha untuk tetap memberikan semangat kepada para siswa untuk tetap mempertahankan jiwa kewirausahaan tersebut.

Bapak ibu guru di SD Muhammadiyah Pakem tidak bekerja sendiri, tetapi mereka kerjanya kerja kolegial, bersama-sama. Jadi, semua informasi disampaikan di team grup whatssapp, kemudian seminggu sekali sekolah tersebut selalu mengadakan rapat. Team di sekolah tersebut kemudian mengevaluasi kegiatan apa saja yang sudah dilaksanakan, dan kegiatan apa saja yang akan dilakukan minggu kedepan. Nanti kalau ada sesuatu misalnya ada tamu atau event, sekolah tersebut mendadak untuk mengadakan pertemuan, tapi rapatnya biasanya rutin hari jumat. Di SD Muhammadiyah Pakem yang ikut pelatihan digilir sesuai dengan bidangnya. Sesuai dengan kapasitas guru dan karyawan masing-masing.

Selain menyedikan fasilitas pendukung, sekolah juga membuat kegiatan seperti marketday yang dilaksanakan setiap tiga bulan sekali. Pembelinya adalah orang tua siswa, para siswa, hingga guru-guru. Guru-guru di SD Muhammadiyah Pakem juga tidak hanya sekedar memberikan materi pelajaran saja. Tetapi juga mendidik dan membimbing siswa-siswinya agar selalu memberikan motivasi kepada siswa untuk menumbuhkan minatnya di bidang kewirausahaan. Di sekolah tersebut juga sudah diajarkan kewirausahaan mulai semenjak kelas 
III. Biasanya guru di sekolah tersebut, sudah mulai membekali para siswa untuk membuat hasil karya, yang akan berguna bagi siswa kelak ketika sudah lulus dari SD Muhammadiyah Pakem.

Di sekolah tersebut ada tim IT, sehingga apapun kegiatan sekolah diupload di media sosial. Hal itu merupakan sebuah usaha untuk mempromosikan dan memperkenalkan sekolah itu sendiri bahwa Sekolah Dasar Muhammadiyah Pakem adalah sekolah yang bagus dalam menerapkan dan mengembangkan manajemen pendidikan di bidang kewirausahaan. Kemudian, siswa di sekolah ini juga pernah mengikuti lomba-lomba di sekolah lain. Apabila di luar ada stand bazar, Sekolah Dasar Muhammadiyah Pakem juga tidak ketinggalan untuk selalu mengikuti lomba-lomba. Hasil karya siswa pun selalu dipajang, sehingga orang tua bisa tahu. Itu juga merupakan sebuah usaha inovasi untuk pengembangan kewirausahaan dalam manajemen pendidikan di Sekolah Dasar.

\section{Pembahasan}

Manajemen pengembangan kewirausahaan yang dilaksanakan di SD Muhammadiah Pakem dilakukan dengan berbagai cara, diantaranya: 1) membekali guru dengan materi kewirausahaan; 2) mengintegrasikan dalam muatan pelajaran; 3) menyediakan sarana dan fasilitas pendukung; 4) membuat kegiatan berbasis kewirausahaan, serta 5) bekerja dengan orang tua. Pengembangan kewirausahaan di sekolah dasar, diawali dengan membekali guru dengan materi kewirausahaan. Oleh sebab itu, pengadaan kegiatan pelatihan yang mengasah kemampuan guru SD dalam hal kewirausahaan sangat perlu untuk dilakukan [6]. Hal ini dimaksudkan agar guru memiliki dasar yang kuat sehingga dapat mengembangkan jiwa kewirausahaan siswa. Disamping itu, peningkatan kemampuan guru ini, tentu tidak lepas dari perilaku inovatif kepala sekolah yang berpengaruh langsung terhadap kinerjanya [7]. Perilaku kepala sekolah yang inovatif ini tentu akan berpengaruh pada implementasi program di sekolah yang dipimpinnya.

Pengintegrasian kewirausahaan dalam muatan pembelajaran merupakan salah satu cara yang paling efektif untuk dilakukan. Hal ini didukung dari hasil penelitian terdahulu yang menyebutkan bahwa untuk dapat menumbuhkan jiwa kewirausahaan dapat dilakukan melalui proses belajar mengajar, ektrakulikuler, dan mata pelejaran kewirausahaan [5]. Kolaborasi antar muatan-muatan pembelajaran dapat mengintegrasikan kewirausahaan didalamnya. Cara ini dianggap efektif dalam mengembangkan kewirausahaan siswa karena guru hanya perlu menyisipkan materi terkait kewirausahaan, dan sekolah tidak perlu membuat kurikulum baru terkait kewirausahaan. Akan tetapi, integrasi program kewirausahaan dalam materi pelajaran juga perlu didukung dengan sarana dan fasilitas yang mendukung.

Keberhasilan kegiatan pembelajaran termasuk pengembangan kewirausahaan pada siswa perlu didukung dengan sarana dan fasilitas yang memadai. Hal ini dimaksudkan agar implementasi program pembelajaran dapat berjalan dengan optimal. Hasil penelitian terdahulu menunjukkan fasilitas dan sarana penunjang berpengaruh signifikan dan positif terhadap hasil belajar siswa [8]. Penelitian lain juga menyebutkan hal yang serupa bahwa sarana dan prasarana yang baik memberi dampak positif terhadap proses dan hasil belajar siswa [9]. Dengan demikian, berbagai sarana dan fasilitas penunjang yang disediakan oleh sekolah tentu akan memberikan pengaruh yang cukup positif terhadap pengembangan kewirausahaan siswa.

Menejemen pendidikan dalam mengembangkan kewirausahaan siswa juga perlu didukung dengan kegiatan praktik nyata. Oleh sebab itu, sekolah juga mengadakan berbagai kegiatan sehingga siswa dapat praktik dan mengembangkan segala dasar-dasar kewirausahaan yang telah dipelajarinya sebelumnya. Kegiatan-kegiatan tersebut dapat dimulai dari hal-hal sederhana yang mudah dijumpai pada keseharian siswa, sehingga dapat memberikan kesempatan kepada siswa untuk mengembangkan kemampuan kewirausahaan [10]. Dengan demikian, kegiatan market day yang dilaksanakan oleh sekolah dapat menundukung pengembangan kewirausahaan dalam diri siswa. 


\section{SIMPULAN}

Karakter seorang anak dibangun melalui apa yang didengarkan dan apa yang dirasakan. Sebagai guru punya peran penting untuk memberikan teladan yang baik. Tidaklah mudah untuk memahamkam kewirausahaan kepada siswa-siswi sekolah dasar. Perlu adanya peningkatan kualitas dari setiap guru agar bisa maksimal dalam memberikan gambaran kewirausahaan kepada siswa-siswi yang tentunya akan sangat membantu ketika di masa depan kelak. Mengenai SDM yang menjadi fokus utama sekolah yaitu dari guru-gurunya. Karena guru memiliki peran penting dalam pengembangan kewirausahaan kepada siswa-siswi. Mata Pelajaran pun yang diajarkan itu berupa matematika, IPS dan juga Agama. Selain mata pelajaran yang berkaitan dengan kewirausahaan, ada beberapa hal juga yang dilakukan untuk menumbuhkan jiwa kewirausahaan setiap siswa-siswi. Seperti dengan berkunjung ke usaha milik orang tua siswa-siswi, atau biasanya juga dengan memanfaatkan dedaunan untuk membuat batik dengan motif yang sederhana saja.

Bentuk Implementasi ini bukan hanya sekedar berlaku dilingkungan sekolah saja. Melainkan ada harapan agar kelak ilmu yang didapatkan siswa-siswi maupun gambaran dalam berbisnis itu sudah ada sejak dini. Selain dengan adanya membuat jus ataupun kerajinan tangan. Sekolah juga membangun tempat untuk menaruh kerajinan tangan maupun hasil produk yang telah dibuat oleh setiap siswa-siswi. Ada beberapa hal yang menjadi fokus utama guru untuk tetap menjaga jiwa kewirausahaan setiap siswa-siswinya yaitu dengan memberikan semangat.

\section{DAFTAR PUSTAKA}

[1] H. Maulana, "Pengembangan jiwa kewirausahaan: studi kasus terhadap mahasiswa yang berwirausaha di Yogyakarta," Jurnal Ecodemica, vol. 2, no. 1, pp. 21-29, 2018, [Online]. Available: https://ejournal.bsi.ac.id/ejurnal/index.php/ecodemica/article/view/2666.

[2] A. A. Gümüsay, "Entrepreneurship from an Islamic perspective," Journal of Business Ethics, vol. 130, no. 1, pp. 199-208, 2015, [Online]. Available: https://philpapers.org/rec/GMSEFA.

[3] H. Y. Hijriah, "Spiritualitas Islam dalam kewirausahaan," Tsaqafah: Jurnal Peradaban Islam, vol. 12, no. 1, p. 187, 2016, [Online]. Available: http://ejournal.unida.gontor.ac.id/index.php/tsaqafah.

[4] W. R. Wahyuni and W. Hidayati, "Peran sekolah dalam membentuk keterampilan wirausaha berbasis tauhid di SD Entrepreneur Muslim Alif-A Piyungan Bantul Yogyakarta," MANAGERIA: Jurnal Manajemen Pendidikan Islam, vol. 2, no. 2, pp. 359377, 2017, [Online]. Available: http://ejournal.uinsuka.ac.id/tarbiyah/manageria/article/view/1624.

[5] J. Maknuni, "Strategi sekolah dasar dalam menumbuhkan jiwa kewirausahaan peserta didik," Jurnal Ilmiah KONTEKSTUAL, vol. 2, no. 2, pp. 9-16, 2021, [Online]. Available: http://jurnal.umus.ac.id/index.php/kontekstual/article/view/392.

[6] M. Faisal, H. Hotimah, N. Nurhaedah, N. AP, and K. Khaerunnisa, "Peningkatan kompetensi guru sekolah dasar dalam mengembangkan bahan ajar digital di Kabupaten Gowa," Jurnal Publikasi Pendidikan, vol. 10, no. 3, pp. 266-270, 2020, [Online]. Available: http://ojs.unm.ac.id/index.php/pubpend.

[7] A. Anjar, M. Siregar, T. Toni, M. K. Ritonga, H. S. Haragap, and Z. A. Siregar, "Pengaruh perilaku inovatif terhadap kinerja kepala sekolah dasar di Kabupaten Labuhanbatu," Jurnal Education and Development Institut Pendidikan Tapanuli Selatan, vol. 8, no. 3, pp. 26-32, 2020, [Online]. Available: http://journal.ipts.ac.id/index.php/ED/article/view/1742.

[8] R. Yuliana, "Pengaruh pembelajaran daring dan fasilitas penunjang terhadap kinerja guru dan hasil belajar siswa," Jurnal Lipnas, vol. 3, no. 2, pp. 1-18, 2021, [Online]. Available: http://journal.umuslim.ac.id/index.php/ltr2/article/view/496/409.

[9] T. Azhari and J. Sahputri, "Hubungan antara sarana pendukung, proses, dan hasil pembelajaran," Jurnal Ilmiah Sains, Teknologi, Ekonomi, Sosial dan Budaya, vol. 5, no. 
2, pp. 33-36, 2021, [Online]. Available: https://jurnallipnas.com/wpcontent/uploads/2021/07/10.-jurnal-nana-1.pdf.

[10] S. Sugianti, R. S. I. Dewi, and S. Maemunah, "Upaya menumbuhkan enterpreneurship anak usia dini melalui kegiatan market day pada kelompok B TK Aqila Yasmin Ceper Klaten," Sentra Cendekia, vol. 1, no. 2, pp. 52-56, 2020, [Online]. Available: http://ejournal.ivet.ac.id/index.php/Jsc/article/view/1296. 